Mitteilungen der Österreichischen Geographischen Gesellschaft, 157. Jg. (Jahresband), Wien 2015, S. 370-372

\title{
$8^{\text {tr }}$ EuroSeAS Conference, Wien, 11.-14. August 2015
}

\author{
Alexander TRUPP, Wien*
}

Im August 2015 wurde Wien als Austragungsort der Konferenz der European Association for Southeast Asian Studies (EuroSEAS) zum internationalen Zentrum der Südostasienwissenschaften. EuroSEAS ist eine international und interdisziplinär ausgerichtete Vereinigung, die 1992 gegründet wurde. Sie ist weltweit der größte Berufsverband für Wissenschafter, die über Südostasien arbeiten (http://www.euroseas.org/). EuroSEAS organisiert im zwei- bis dreijährlichen Rhythmus die wichtigste Südostasienkonferenz, die zuletzt im Juli 2013 in Lissabon [Lisboa] stattfand.

Das zwischen den Großmächten Indien und China liegende Südostasien entwickelte sich aufgrund der besonders dynamisch ablaufenden ökonomischen, demographischen, sozialen und ökologischen Transformationen zur wichtigen Untersuchungsregion für sozial-, kultur-, umweltwissenschaftliche und geographische Forschung. Über 500 Wissenschafter aus unterschiedlichen Disziplinen diskutierten in 80 Panels zu so vielfältigen Themenbereichen wie (post)koloniale Geschichte, Regionalpolitik, Demokratisierung, Ethnizität, Mobilitäten, Stadtentwicklung, Neue Medien, Gender und Körper, soziale Ungleichheit, Religion, Literatur, Kunst und natürliche Ressourcen.

Diese thematische Bandbreite spiegelt die Vielfalt an Südostasienstudien wider, und so war es eine bewusste Entscheidung des EuroSEAS-Komitees, die Themenbandbreite nicht im Vorfeld der Konferenz einzuschränken. Darüber hinaus widmeten sich vier Roundtable-Diskussionen aktuellen Themen wie den politischen Entwicklungen in Südostasien, dem Wahljahr in Myanmar (2015) und einer Debatte zu Südostasienstudien als Regionalwissenschaft.

Die EuroSEAS-Konferenz ist die weltweit größte Südostasientagung und fand in ihrer achten Ausführung zum ersten Mal in Wien statt. Die lokale Organisation wurde federführend vom Institut für Sozial- und Kulturanthropologie (Gabriele WEICHART) der Universität Wien, dem Institut für Sozialanthropologie (Martin SLAMA) der Österreichischen Akademie der Wissenschaften (ÖAW) und dem EuroSEAS-Sekretariat (Yayah SIEGERS) des Königlichen Niederländischen Instituts für Südostasien- und Karibische Studien [Koninklijk Instituut voor Taal-, Land- en Volkenkunde, KITLV] in Leiden durchgeführt. Des Weiteren war eine Reihe von Mitgliedern verschiedener Institute der Universität Wien (Politikwissenschaft, Geographie, Ostasienwissenschaft, Internationale Entwicklung), der Technischen Universität Wien, des Weltmuseums Wien und der Gesellschaft für Südostasienstudien (SEAS) im Organisationskommittee an den Vorbereitungen und der Durchführung beteiligt. Dem Hauptsponsor der Konferenz, Nikkei Asian Review, ist dafür zu danken, dass die Reisekosten zahlreicher Jungakademiker aus Südostasien finanziert werden konnten.

Südostasienforschung in Wien existiert allerdings nicht erst 2015. So erinnerte Andre GINGRICH in seiner Begrüßungsrede im Festsaal der Österreichischen Akademie der Wissenschaften daran, dass die Erkenntnisse der im 19. Jh. durchgeführten Novara-Weltumsegelung, die auch nach Süd-

\footnotetext{
* Mag. Dr. Alexander Trupp, Institute for Population and Social Research, Mahidol University, Phutthamonthon Sai 4 Rd., Salaya, Nakhon Pathom 71170, Thailand; E-mail: alexander.tru@mahidol.ac.th
} 
ostasien führte, mit Unterstützung der ÖAW publiziert werden konnten. Anfang des 20. Jhs. war Wien neben London und Amsterdam eines der weltweit bedeutendsten Zentren der Südostasienwissenschaften, in dem damals international bekannte Persönlichkeiten wie Paul SCHEBESTA oder Robert VON HEINE-GELDERn forschten, lehrten und publizierten.

Interessant ist in diesem Zusammenhang auch, dass der Regionsbegriff Südostasien auf den österreichischen Ethnologen Robert vON HEINE-GELDERN (1885-1968) zurückgeht, dessen Geburtstag sich 2015 zum 130. Mal jährte. Obwohl es in Österreich kein universitäres Zentrum für Südostasienstudien gibt, wurde und wird diese Wissenschaftstradition an verschiedenen Instituten weitergeführt, was sich nicht zuletzt auch in der EuroSEAS-Konferenz widerspiegelte.

Der erste Hauptredner der Konferenz war am Eröffnungstag Bendict ANDERson, dessen wissenschaftliche Wirkungsgeschichte weit über die Region Südostasien hinausreicht. In dem bis auf den letzten Platz gefüllten und aufgrund der ungewöhnlich heißen Außentemperaturen tropisch-warmen Festsaal der ÖAW plädierte er in seiner Rede „Alarms of an Old Alarmist“ für eine mutigere Wissenschaft, die sich nicht von Geld oder mafiösen Strukturen irreleiten lassen dürfe und warnte zugleich vor allzu engen Verbindungen zwischen Politik und Forschung.

Die zweite Keynote mit dem Titel „The Spirit of Indonesia: Rasa, Reason, Religion” fand am 12. August an der Universität Wien statt und wurde von der bedeutenden indonesischen Autorin Ayu UTAMI gehalten.

Das Panelprogramm vom 12. bis 14. August fand in den Räumlichkeiten des Hauptgebäudes der Universität Wien am Ring statt und verteilte sich auf bis zu elf parallele Sitzungen, von denen man - wie bei allen größeren Konferenzen - naturgemäß nur eine kleine Auswahl direkt mitverfolgen konnte. Von Teilnehmern aus Österreich wurden dabei folgende wissenschaftliche Panels organisiert:

- Heine-Geldern and the Making of Southeast Asia: Scholarly Connections and Cultural Legacies across Regime Changes (Marieke BloEmbergen, Koninklijk Instituut voor Taal-, Landen Volkenkunde, KITLV \& Andre Gingrich, Austrian Academy of Sciences)

- The Changing Notion of Security in Southeast Asia (Alfred GerstL, University of Vienna \& Mária StrašÁKOvÁ, Metropolitan University Prague)

- Transnational Mobilities Into and Out of Thailand (Sirijit SunANTA, Mahidol University \& Alexander TRUPP, University of Vienna)

- Recent Developments in Philippine Migration within Asia (Fiona SeIger, University of Vienna)

- Tourism and Development in Southeast Asia: Unravelling the Complexities of Tourism for Poverty Alleviation (Claudia Dolezal, University of Brighton \& Alexander TRUPP, University of Vienna)

- Islamic (Inter)Faces of the Internet in Southeast Asia (Martin Slama, Austrian Academy of Sciences)

- Is Gender Women? Taking Stock of Southeast Asian Studies on Gender (Petra Dannecker, University of Vienna \& Martina Padmanabhan, University of Passau)

- Vernacular Architecture: Transitions from Traditional to Contemporary (Ulrike HeRBIG \& Ferenc Zámolyı, Technical University Vienna)

- Analyzing Socio-Ecological Conflicts from a Political Ecology Perspective (Alina BRAD \& Melanie PICHLER, University of Vienna)

Das gesamte Konferenzprogramm einschließlich des Book of Abstracts kann online unter http:// www.univie.ac.at/euroseas2015/ nachgesehen werden. Die österreichische Geographie war dabei durch folgende Fachvorträge repräsentiert: 
- Thai Marriage Migrants in Austria (Kosita Butratana, University of Vienna - Department of Geography and Regional Research)

- Thai Outbound Tourism to Europe (Alexander TRupP, University of Vienna - Department of Geography and Regional Research)

- Receiving and Providing Care Abroad - Interactions between International Retirement Migration and the Elderly Care Sector in Chiang Mai, Thailand (Christina Maria VogLer, University of Vienna - Department of Geography and Regional Research)

- Mediating Southeast Asia: An Exploration of Geographies of Identity, Power and Imagination in Popular Guidebooks and Travelblogs (Felix Magnus Bergmeister, University of Vienna Department of Geography and Regional Research)

- Tourism, Migration and Development: Perspectives for Urban-based Hilltribes in Thailand (Alexander TrupP, University of Vienna - Department of Geography and Regional Research)

- Conflict and Commodification of Water: Political Ecology of Bottled Water Industries in Indonesia (Yosafat Hermawan Trinugraha \& Martin CoY, University of Innsbruck - Department of Geography)

In den Pausen hatten die Teilnehmer die Möglichkeit, an den Büchertischen relevanter Südostasienreihen und Verlage wie etwa Routledge, NIAS Press, GIGA, ASEAS oder Nikkei Asian Review zu schmökern und Kontakte für Publikationsmöglichkeiten eigener Forschungen zu knüpfen.

Zusätzlich zum wissenschaftlichen Panelprogramm wurden im Audimax der Universität Wien Kinofilme zu und aus Indonesien, Thailand und Myanmar mit anschließenden Diskussionsrunden gezeigt sowie im Café Prückel ein Literaturabend mit der Autorin und Journalistin Ayu UTAMI aus Indonesien als Hauptrednerin veranstaltet.

Die EuroSEAS-Konferenzen werden in Zukunft im Zweijahresrhythmus veranstaltet und ein großer Teil der diesjährigen Teilnehmer wird sich sicher auch 2017 bei der nächsten Konferenz in Oxford wiedersehen. 